\title{
REVIEW
}

\section{Thirty years of the human immunodeficiency virus epidemic and beyond}

\author{
Fariba S Younai
}

After more than $\mathbf{3 0}$ years of battling a global epidemic, the prospect of eliminating human immunodeficiency virus (HIV) as the most challenging infectious disease of the modern era is within our reach. Major scientific discoveries about the virus responsible for this immunodeficiency disease state, including its pathogenesis, transmission patterns and clinical course, have led to the development of potent antiretroviral drugs that offer great hopes in HIV treatment and prevention. Although these agents and many others still in development and testing are capable of effectively suppressing viral replication and survival, the medical management of HIV infection at the individual and the population levels remains challenging. Timely initiation of antiretroviral drugs, adherence to the appropriate therapeutic regimens, effective use of these agents in the pre and post-exposure prophylaxis contexts, treatment of comorbid conditions and addressing social and psychological factors involved in the care of individuals continue to be important considerations. International Journal of Oral Science (2013) 5, 191-199; doi:10.1038/ijos.2013.76; published online 18 October 2013

Keywords: human immunodeficiency virus; treatment; prevention; global impact; antiretrovirals; epidemiology

\section{BACKGROUND}

In 1981, the first cases of a deadly new infectious disease occurring in previously healthy gay men and manifested by Pneumocystis pneumonia and Kaposi's sarcoma, were reported in New York and Los Angeles. ${ }^{1}$ Shortly after these initial reports, news of infection among a small number of migrants from the Caribbean island of Haiti as well as individuals with a history of hemophilia and injection drug use started to surface. ${ }^{2-6}$ The condition was given a number of names in the American and the European popular press (including the gay-related immune deficiency) and in September 1982, the US Centers for Disease Control began referring to it as 'acquired immune deficiency syndrome' or 'AIDS'. In 1983, as cases of AIDS started to manifest among female sexual partners of infected men, ${ }^{8-9}$ the causative agent was identified and later named 'human immunodeficiency virus type 1' or 'HIV-1'; ${ }^{10-12}$ in 1985, the enzyme immunoassay test for HIV-1 antibodies became available; ${ }^{13}$ and in 1986, HIV-2 was isolated from patients diagnosed with AIDS in West Africa. ${ }^{14}$ Since its original description 32 years ago, HIV has become one of the most significant infectious diseases worldwide and has challenged public health systems in every country affected by the epidemic. This article provides an overview of the HIV disease epidemic including its global impact, viral pathogenesis, important clinical features and many of the current medical management and prevention strategies employed. Although comprehensive in nature, portions of this review focuses on USA data to help highlight specific issues.

\section{THE ORIGIN OF HIV}

HIV-1 is closely related to the simian immunodeficiency viruses $\operatorname{SIV}_{\mathrm{cpz}}$ from the Troglodytes chimpanzees and the $\mathrm{SIV}_{\text {gor }}$ found in the Western lowland gorillas, whereas HIV-2 is similar to the $\mathrm{SIV}_{\text {sm }}$ from the sooty mangabey monkeys; these primates inhabit Cameroon and Congo in Central Africa and in Ivory Coast in Western Africa, respectively. ${ }^{15-17}$ Although it is now widely accepted that HIV originated from crossspecies transmission of these simian immunodeficiency viruses from the primates to humans, the causes of its original spread among human populations is still under much debate. It has been postulated that a combination of urbanization and departure from traditional life styles, prostitution and spread of sexually transmitted diseases, large public health campaigns coupled with poor infection control methods, contributed to the development of a perfect environment where HIV gained a foothold and spread among many African nations and the migrant Haitian workers in the region many years before its original reports in the USA and Western Europe. ${ }^{18-19}$

\section{GLOBAL EPIDEMIOLOGY}

The current global estimate for people living with the HIV or AIDS diagnoses is 34 million. ${ }^{20}$ Worldwide, there were 2.7 million new HIV infections in 2010, including 390000 children, numbers that were $21 \%$ below the number of new infections at the peak of the epidemic in $1997 .^{20}$ The very encouraging observation of a globally reduced HIV incidence in 33 countries, 22 of them in Sub-Saharan Africa the region most affected by the AIDS epidemic, coupled with the wider availability of antiretroviral (ARV or ART) therapies and intervention programs that have especially targeted maternal-child transmission, have made possible the vision of a world with zero new HIV infections. In fact, in South and South-East Asia, the estimated new HIV infections in 2010 was $40 \%$ less than at the epidemic's peak in 1996, and in India, new HIV infections fell by $56 \%$ in the same time period. ${ }^{20}$ However, 
despite these reductions, certain regions of the world continue to experience a very high disease burden; in Sub-Saharan Africa, the adult HIV prevalence rate is as high as $5.2 \%$; the Caribbean region has the second highest regional HIV prevalence after Sub-Saharan Africa; in Eastern Europe and Central Asia, the number of people living with HIV rose by 250\% from 2001 to 2010; and in Latin America, although the number of new HIV infections has remained stable, the proportion of women living with HIV is growing. ${ }^{20}$

Globally, the predominant HIV transmission mode is heterosexual with two broad patterns identified. One is the generalized epidemic pattern seen in many Sub-Saharan African countries and the other is the epidemic seen in the rest of the world that is primarily concentrated among populations most at risk. ${ }^{21}$ The at-risk populations include men who have sex with men, injecting drug users and sex workers and their sexual partners. ${ }^{21}$

\section{HIV STRUCTURE AND LIFE CYCLE}

HIV is an enveloped retrovirus that appears spherical in shape with a number of spikes on its surface. ${ }^{22}$ The viral core consists of a protein capsid called p24, two linear RNA molecules and three enzymes called reverse transcriptase, integrase and protease. The bilayer viral envelope consists of knob-like spikes, each made of an external glycoprotein gp120 and a transmembrane glycoprotein gp41 and an underlying layer called the matrix, the protein p17, derived from the virus' previous host cell membrane. ${ }^{23-24}$ The HIV genome consists of three structural and at least six regulatory genes. ${ }^{25}$ The structural genes include Env encoding for the viral envelope proteins gp 120 and gp 41, Gag encoding for the matrix and core proteins p17 and p24 and Pol encoding for the key viral enzymes protease, reverse transciptase and integrase. $^{25}$ The regulatory genes include Tat, Rev, Nef, Vif, Vpr, Vpx and $V p u .{ }^{25}$ After exposure to HIV, successful establishment of infection involves a series of steps and a complex interaction between the virus, its regulatory genes and the host immune system. Stages of HIV infection consist of viral binding and entry, HIV RNA replication and integration, viral assembly, budding and release of new virions.

HIV entry involves an initial weak interaction between gp120 and surface molecules such as $\alpha_{4} \beta_{7}$ integrin and DC-SIGN followed by a high affinity interaction with $\mathrm{CD} 4$, the primary receptor on $\mathrm{CD} 4{ }^{+} \mathrm{T}$ cells and also found on the surface of monocytes, dendritic cells and brain microglia. ${ }^{26-27}$ HIV-host cell interaction also involves the natural chemokine receptors, CCR5 and CXCR4, which act as coreceptors for HIV anchorage and entry into the host cell. ${ }^{28}$ This is accomplished after the initial CD4 binding and by the HIV gp120 undergoing conformational changes that expose the binding sites for the chemokine receptors. ${ }^{29}$ The strain of HIV that has an affinity for the CCR5 receptor is referred to as the R5 strain, the predominant type of HIV in mucosal transmissions and seen in the early years of infection; this is distinct from the X4 strain of HIV that primarily uses the CXCR4 coreceptor and is seen in blood-borne transmissions and later in the course of HIV diseases. ${ }^{30-31}$ It has been shown that a genetically variable region of the gp120 (V3 region) plays an important role in determining the HIV coreceptor interaction. ${ }^{32-33}$

After entry into the host cell, HIV may remain dormant for a long time inside the cell or begin its replication process by penetrating the host cell nucleus. Once there, the HIV RNA is reversely transcribed, mediated by the reverse transcriptase enzyme to form, first one, and then a second DNA molecule (proviral DNA), which gets integrated into the host DNA, a process that is mediated by the integrase enzyme. ${ }^{25}$ It is this DNA that serves as a blueprint for making messenger RNAs that are transported outside the host cell nucleus to help synthesize the new viral genetic material, proteins and enzymes necessary for forming the new viral particles. In this process of assembly, the enzyme protease plays a vital role by chopping up long strands of proteins into smaller pieces necessary for constructing the new mature viral cores. The newly matured HIV particles are ready to be released by budding from the surface of the host cell membrane so they can infect another cell and begin the replication process all over again.

Many of the factors described in the HIV life cycle have been used as targets for developing antiretroviral drugs. These agents will be discussed under HIV disease management.

\section{HIV INFECTION AND HOST FACTORS}

A small subset of ARV-untreated HIV-infected individuals (about $3 \%-5 \%$ ) can maintain normal CD4 cell counts for many years (long-term non-progressors), and an even smaller subset $(\sim 1 \%)$ can maintain suppressed viral loads for years (elite controllers). ${ }^{34-35}$ Several mechanisms have been proposed for these uncommon host responses to HIV infection and progression. One is the wide genetic variability in the way people express the kemokine coreceptors on their HIV target cells. It is this genetic determinant that influences the level of susceptibility to HIV infection and disease progression-people without the full coreceptor expression are either immune to HIV infection or their HIV disease do not progress as rapidly compared to people who have the full genetic expression. One reported genetic mutation involves a 32-base pair deletion in CCR5 receptor (CCR5$\Delta 32$ allele) that infers resistance in those who are homozygote for the mutation and slow progression for the heterozygotes, a category that includes some of the clinically defined long-term non-progressors. ${ }^{36-37}$ The CCR5- $\Delta 32$ allele is mainly present in Europeans, people from the Baltic Sea and Central Russia (10\% on average), is found with the lowest frequency in the Mediterranean area, North Africa, Middle East, Central Asia and is absent in Sub-Saharan Africa, East and Southeast Asia. ${ }^{38}$

The long-term non-progressors have a slower course of HIV progression as defined by CD4 depletion but many ultimately progress to AIDS. ${ }^{39}$ In contrast, the elite controllers are at a very low risk for progression to AIDS, as defined by maintaining a low viral load for many years and despite absence of treatment. ${ }^{39}$ For these individuals, the long-term viral suppression may be due to a number of factor that include attenuated viral strains, having protective HLA alleles (HLAB27 and -B57), strong innate immune responses involving the natural killer cells and effective viral restriction factors. ${ }^{40}$ One restriction factor that has gained a lot of attention is the innate host defense molecule 'Apolipoprotein B or APOBEC 3G', a polypeptide responsible for amino-acid substitution on newly synthesized viral DNA that functions in interrupting HIV replication. ${ }^{41-42}$ Another host defense molecule 'Tetherin', a membrane protein (CD317) with nonspecific antiviral properties, can block the envelope protein release. ${ }^{43}$ Of all the HIV regulatory genes, Vif has been shown to have the potential to cripple the APOBEC 3G function and viral Vpu appears to have the same potential against Tetherin, highlighting the important roles of the HIV regulatory genes and their products in establishing successful infection and disease progression. ${ }^{43-44}$

\section{MECHANISMS AND REGIMENS OF ANTI-RETROVIRAL DRUGS}

Remarkable scientific advances of the past three decades have uncovered the HIV viral factors and mechanisms that together with a better understanding of the host immune responses have provided the basis for developing several potent antiretroviral agents. The currently 
approved and commercially available ARV agents and combination drugs target specific HIV replicative stages and consist of: (i) nucleoside and nucleotide analog reverse transcriptase inhibitors (NRTI and NtRTI); (ii) non-nucleoside reverse transcriptase inhibitors (NNRTI); (iii) protease inhibitors (PI); (iv) fusion inhibitors; (v) integrase inhibitors (INSTI or integrase strand transfer inhibitors); (vi) entry inhibitors that currently consist of CCR5 antagonists; and (vii) combination agents. ${ }^{45}$ The primary aim of anti-HIV treatment is to provide durable suppression of HIV replication to a level that is below the detection limits for plasma HIV quantification viral assays. ${ }^{46}$ Durable viral suppression results in both, fewer drug-resistant viral variants, and prevents HIV transmission; resistance occurs through random mutations during the high rate of HIV replication and mostly because of poor patient adherence to the medication regimens. There are currently 36 Food and Drug Administration (FDA)-approved single or combination ARV drugs on the market and a number of compounds in line for future FDA approval pending their completion and testing. Table 1 shows a listing of these antiretroviral agents, their properties and many of their associated adverse effects. ${ }^{45,47}$

The most recent recommended combination regimens for treatment-naive patients consist of two NRTIs as the therapeutic backbone plus one NNRTI (called an NNRTI-based regimen), or a boosted PI (called a PI-based regimen) or an INSTI (called an INSTI-based regimen) ${ }^{45}$ Usually, an NNRTI-based regimen is used first and in case of virological or immunological failure, it is changed into a PI-based or an INSTI-based regimen (Table 2). Virological failure in a patient can occur because of poor patient drug adherence, drug intolerance/toxicity or pre-existing (transmitted) drug resistance; it is more likely with higher HIV RNA levels and/or lower CD4 T-cell counts at baseline, prior AIDS diagnosis and comorbidities such as active substance abuse and depression. ${ }^{47} \mathrm{HIV}$ drug-resistance testing is recommended for persons with HIV infection when entering into care and when changing ARV regimens after virological failure. ${ }^{47}$ Genotypic testing is recommended as the preferred resistance testing to detect mutations in the reverse transcriptase and protease genes, while phenotypic assays, measuring the ability of a virus to grow in different concentrations of ARV drugs, is recommended for persons with known or suspected complex drug resistance mutation patterns, particularly to PIs. ${ }^{47}$ Once virological failure is confirmed, the regimen should be changed as soon as possible to avoid progressive accumulation of resistance mutations. ${ }^{48}$ In that case, the regimen of choice will depend on the person's treatment history and resistance testing and should involve a new mechanistic class. ${ }^{47}$ Immune-based therapies such as interleukin-2 (IL-2), IL-7, gene therapies, growth hormone and cyclosporine are not currently included in the HIV treatment recommendations. ${ }^{47}$

\section{HIV DISEASE MANAGEMENT}

HIV infection leads to a spectrum of manifestations that progress from asymptomatic infection to a state of severe immunological suppression associated with opportunistic fungal, viral and bacterial infections and malignancies. The immunological suppression seen in HIV infection, results from a number of immunological defects that include severe reduction in the CD4-positive T lymphocytes, cytokine dysregulation and defective innate immune responses. ${ }^{49-52}$ The magnitude of the immunological suppression determines both individuals' initial disease manifestations and also response to treatment. The initial evaluation of a patient with HIV infection is complex and should include not only the medical status but also many factors in the social, psychological and psychiatric domains that can influence a person's ability to adhere to the therapeutic drug regimens. Assessment of high-risk behaviors, substance abuse, social support, mental illness, economic factors and housing, medical insurance status and adequacy of coverage are all important considerations. ${ }^{47}$ In addition, tests for sexually transmitted infections, hepatitis $\mathrm{C}$ and tuberculosis should also be a part of the initial and ongoing assessments and, if detected, their treatment must be included in the person's comprehensive care plan. $^{53}$

One key consideration in HIV disease management is the timing of antiretroviral therapy (ART) in relationship with patient's HIV disease state. The current recommendations for initiating ARV treatment is as early as possible in the course of HIV infection and definitely before patient's CD4 count goes below $350 \mathrm{~mm}^{-3} \cdot 47$ The strong recommendation for initiation of ARV for CD4 counts at values between 350 and $500 \mathrm{~mm}^{-3}$ is based on existing evidence from randomized controlled trials, well-designed non-randomized trials and observational cohort studies, while the recommendation to start ARV when CD4 is $>500 \mathrm{~mm}^{-3}$ is based on expert opinion. ${ }^{47}$ Other factors that call for earlier therapy include rapidly declining CD4 count, high viral load, the presence of comorbid conditions and other clinical indications such as chronic HBV infection and HIV-associated nephropathy. ${ }^{47}$ In general, CD4 count and plasma HIV RNA (viral load) should be measured in all patients at baseline and on a regular basis thereafter (every 3-4 months), as the CD4 count values help guide ARV treatment initiation and prophylaxis for opportunistic infections, and viral load is the most important indicator of response to ART. ${ }^{47}$

Side effects associated with long-term use of ARVs are mostly related to metabolic complications and cardiovascular disease. Metabolic complications include hyperglycemia, insulin resistance and hyperlipidemia (elevations in total cholesterol, low-density lipoprotein and triglycerides) mostly caused by many of the older formulations of PIs. ${ }^{54}$ Lipoatrophy or peripheral fat-wasting occurs with the NRTI use, while visceral fat deposition is seen with PIs and is associated with hyperinsulinemia and dyslipidemia. ${ }^{55-56}$ These metabolic alterations coupled with the changes in body composition (with loss of subcutaneous fat and/or accumulation of visceral fat), inflammation and the direct effects of the virus on the vasculature increase the risk for coronary heart disease and require preventive measures. ${ }^{57-59}$ Other consequences of ARV use include osteoporosis and avascular necrosis in bones, prostate neoplasia and lethal solid tumors such as nonHodgkin lymphoma that are mostly associated with NNRTIs. ${ }^{60-62}$ Because of the side effects associated with many classes of ARVs, risk factors for cardiovascular disease, such as hypertension, hyperlipidemia, diabetes and tobacco use, should be aggressively managed in all patients. $^{63-64}$

As many as $20 \%$ of patients who start ARV treatment may experience specific clinical events associated with immune reconstitution inflammatory syndrome. ${ }^{65-68}$ This phenomenon, reported among people who start treatment when their CD4 counts are very low and their viral loads are very high, consists of clinical emergence of a prior subclinical infection or severe recurrence of an old condition. ${ }^{68}$ Manifestations of immune reconstitution inflammatory syndrome have been reported to include mostly dermatological lesions such as anogenital herpes, genital warts, molluscum contagiosum and varicella zoster, as well as other conditions like mycobacterial infections, hepatitis B and Kaposi's sarcoma. ${ }^{67-68}$

\section{HIV PREVENTION STRATEGIES}

Global and regional approaches to HIV prevention are focused on eliminating perinatal transmission cases though effective prevention of mother-to-child transmission (PMTCT) initiatives, early identifiation 
Table 1 Major anti-retroviral drugs

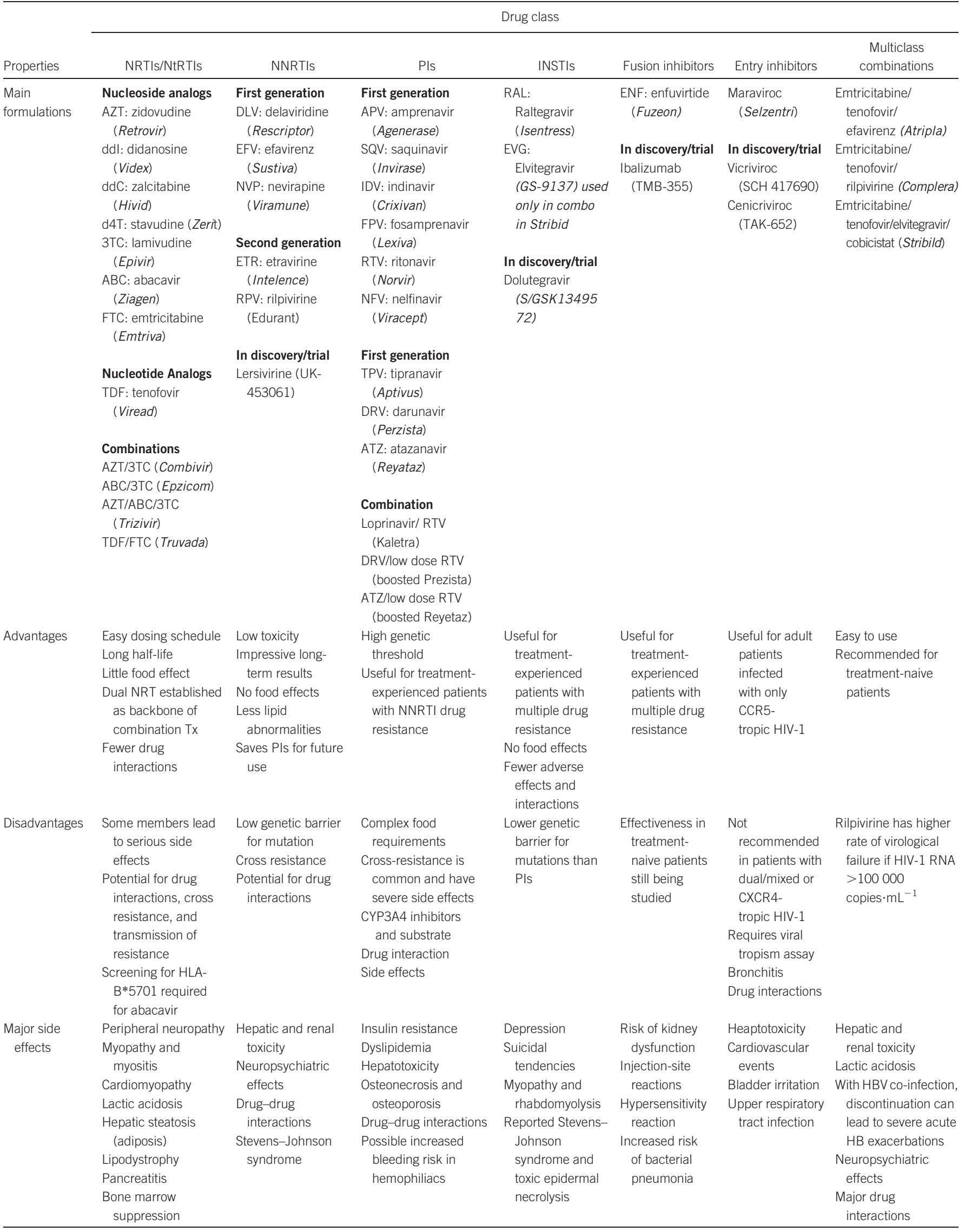


Table1 continue

\begin{tabular}{|c|c|c|c|c|c|c|c|}
\hline \multirow[b]{2}{*}{ Properties } & \multicolumn{7}{|c|}{ Drug class } \\
\hline & NRTIs/NtRTIs & NNRTIs & Pls & INSTIS & Fusion inhibitors & Entry inhibitors & $\begin{array}{c}\text { Multiclass } \\
\text { combinations }\end{array}$ \\
\hline $\begin{array}{l}\text { Common side } \\
\text { effects }\end{array}$ & $\begin{array}{l}\text { Nausea, vomiting, } \\
\text { abdominal pain, } \\
\text { diarrhea, loss of } \\
\text { appetite, lethargy, } \\
\text { muscle weakness, } \\
\text { insomnia, } \\
\text { headache, } \\
\text { dizziness }\end{array}$ & $\begin{array}{l}\text { Nausea, vomiting, } \\
\text { diarrhea, } \\
\text { insomnia, } \\
\text { unusual or vivid } \\
\text { dreams, dizziness, } \\
\text { rash }\end{array}$ & $\begin{array}{l}\text { Nausea, vomiting, } \\
\text { diarrhea, rash, } \\
\text { headache }\end{array}$ & $\begin{array}{l}\text { Nausea, diarrhea, } \\
\text { fever, headache }\end{array}$ & $\begin{array}{l}\text { Fatigue, } \\
\text { numbness in } \\
\text { feet or legs, } \\
\text { dizziness, } \\
\text { insomnia }\end{array}$ & $\begin{array}{l}\text { Nausea, cough, } \\
\text { fever, } \\
\text { dizziness, } \\
\text { headache, } \\
\text { bloating and } \\
\text { distention }\end{array}$ & $\begin{array}{l}\text { Diarrhea, nausea, } \\
\text { fatigue, headache, } \\
\text { dizziness, } \\
\text { depression, } \\
\text { insomnia, abnormal } \\
\text { dreams and rash }\end{array}$ \\
\hline
\end{tabular}

NNRTI, non-nucleoside reverse transcriptase inhibitors; NRTIs, nucleoside analog reverse transcriptase inhibitors; NtRTIs, nucleotide analog reverse transcriptase inhibitors; PI, protease inhibitors.

Table 2 Initial combination regimens for the antiretroviral naive patient

\begin{tabular}{|c|c|c|}
\hline Regimens & Chemical names & Common trade names \\
\hline \multicolumn{3}{|l|}{ Preferred regimen } \\
\hline \multicolumn{3}{|l|}{ NNRTI-based regimens } \\
\hline NRTI/NRTI/ NNRTI & tenofovir/emtrcitabine/efavirenz & Atripla \\
\hline \multicolumn{3}{|l|}{ PI-based regimens } \\
\hline NRTI/NRTI + boosted PI & tenofovir/emtrcitabine + ritonavir/atazavir & Truvada + Boosted Reyetaz \\
\hline NRTI/NRTI + boosted PI & tenofovir/emtrcitabine + ritonavir/darunavir & Truvada + Boosted Prezista \\
\hline \multicolumn{3}{|l|}{ INSTI-based regimen } \\
\hline NRTI/NRTI + INSTI & tenofovir/emtrcitabine + raltegravir & Truvada + Isentress \\
\hline \multicolumn{3}{|l|}{ Alternative regimen } \\
\hline \multicolumn{3}{|l|}{ NNRTI-based regimens } \\
\hline \multirow{3}{*}{ NRTI/NRTI + NNRTI } & emtricitabine/tenofovir/rilpivirine & Complera \\
\hline & abacavir/lamivudine + efavirenz & Epzicom + Sustiva \\
\hline & abacavir/lamivudine + rilpivirine & Epzicom + Edurant \\
\hline \multicolumn{3}{|l|}{ Pl-basedrRegimens } \\
\hline \multirow[t]{4}{*}{ NRTI/NRTI + boosted PI } & abacavir/lamivudine + ritonavir/atazavir & Epzicom + Boosted Reyetaz \\
\hline & abacavir/lamivudine + ritonavir/darunavir & Epzicom + Boosted Prezista \\
\hline & $\begin{array}{l}\text { abacavir/lamivudine or tenofovir/emtrcitabine } \\
+ \text { ritonavir/fosamprenavir }\end{array}$ & Epzicom or Truvada + Boosted Lexiva \\
\hline & $\begin{array}{l}\text { abacavir/lamivudine or tenofovir/emtrcitabine } \\
\text { + ritonavir/loprinavir }\end{array}$ & Epzicom or Truvada + Kaltetra \\
\hline \multicolumn{3}{|l|}{ INSTI-based regimen } \\
\hline \multirow[t]{2}{*}{ NRTI/NRTI + INSTI } & abacavir/lamivudine + raltegravir & Epzicom + Isentress \\
\hline & tenofovir/emtrcitabine/cobistat/elvitegravir & Stribid \\
\hline
\end{tabular}

NNRTI, non-nucleoside reverse transcriptase inhibitors; NRTIs, nucleoside analog reverse transcriptase inhibitors; NtRTIs, nucleotide analog reverse transcriptase inhibitors; PI, protease inhibitors.

of infections through testing and linkage to care programs and protecting uninfected high-risk individuals against HIV transmission.

\section{Perinatal HIV transmission}

In high-income countries, identification of HIV-infected pregnant women and the use of ARV prophylaxis have been very successful in reducing the number of mother-to-child transmissions. For instance, in the United States, the number of perinatal transmissions dropped from 945 cases in 1992 to 48 cases in $2004 .{ }^{69}$ However, in low- to middle-income countries, nearly half of all HIV-positive pregnant women may not be receiving any intervention and remain at risk for disease progression and transmission to their unborn child. ${ }^{70}$ The global goal in PMTCT has recently been updated to include: (i) provision of lifelong ART for HIV-infected women who are in need of treatment (CD4 count $<350 \mathrm{~mm}^{-3}$ ) in order to protect their own health and also to prevent transmission to their child; and (ii) shortterm combination ARV prophylaxis for HIV-infected women who are not in need of treatment (CD4 count $>350 \mathrm{~mm}^{-3}$ ) in order to prevent transmission of HIV to their child during pregnancy, delivery and breastfeeding. ${ }^{71-73}$

\section{Male circumcision}

Clinical trials in Kenya, South Africa and Uganda indicate that voluntary medical male circumcision reduces the risk of female-to-male sexual transmission by about $60 \%{ }^{20}$ To maximize the benefits of this prevention strategy, men of all ages must be targeted for medical male circumcision. It is estimated that in Eastern and Southern Africa, 20 million males need to be circumcised and if this goal is achieved, it will avert approximately 3.4 million new HIV infections by $2015 .^{20}$

\section{Treatment as prevention}

Antiretrovairal treatment not only averts AIDS-related complications and deaths by preventing HIV disease progression, also reduces the 
risk of HIV transmission by lowering individuals' viral loads. ${ }^{74}$ For this reason, universal access to treatment has been a major focus of the HIV intervention programs throughout the world. The most dramatic increases in antiretroviral therapy coverage have occurred in SubSaharan Africa where universal access to treatment (defined as $80 \%$, or greater coverage) has been achieved in Botswana, Namibia and Rwanda, while in countries such as Latvia, Nepal and Sudan, this percentage is still at below $19 \% .^{20}$

\section{Universal HIV screening}

A significant percentage of individuals who are infected with HIV are unaware of their HIV infection. A national study in Kenya showed only $16 \%$ of HIV-infected adults knew that they were infected, while in the United States, this percentage is currently about $20 \% .^{75-76}$ HIV screening is an effective prevention tool because it can help with early identification and treatment of those infected and also because the newly diagnosed are less likely to engage in unprotected sex and with multiple partners. ${ }^{20}$ Universal HIV screening was implemented in the United States in 2006; however, because fear of social stigma is still a key prohibitive factor for universal HIV screening in many regions of the world, in the 2012 Joint United Nations Programme on HIV/AIDS report, the implementation of home HIV testing is identified as a significant HIV prevention strategy for the next decade. ${ }^{20}$

\section{Non-occupational post-exposure prophylaxis and pre-exposure prophylaxis}

Recent approaches to protecting individuals who are at risk for HIV infection target sexually transmitted infections and involve preand post-exposure prophylaxis. In the United States, based on the recommendations issued by the US Centers for Disease Control, individuals who report a non-occupational exposure to infectious body fluids with an HIV-infected source or a high-risk exposure, should receive a 28-day course of ART as prophylaxis against HIV infection (non-occupational post-exposure prophylaxis) and the daily use of tenofovir/emtricitabine (Truvada) is recommended as pre-exposure prophylaxis of HIV-uninfected high-risk gay men and partners of gay and heterosexual serodiscordant couples. ${ }^{77-79}$ The rationale for these recommendations are provided by encouraging results from clinical trials conducted in Botswana, Zambia and South Africa. ${ }^{80-81}$

A recent mathematical model showed that a combination intervention program of HIV that consists of screening, early ART, male circumcision, the use of microbicides and pre-exposure prophylaxis can avert $62 \%$ of HIV infections, while only two interventions of HIV screening and early ART can reduce infections by $34 \% .{ }^{82}$

\section{NEW INTERVENTION STRATEGIES}

The new intervention methods in HIV management and prevention target gene-based therapies, interference with HIV receptor and coreceptor interactions, the use of effective innate immune host factors, eliminating the HIV cellular reservoirs, and reducing the role chronic inflammation in HIV progression. These approaches are explored for their potential in enhancing the conventional HIV medical treatments and also in developing an effective HIV vaccine in the near future.

\section{Gene-based therapies}

In 2009, a single case of HIV cure in Germany received a great deal of attention by the scientific community and the mass media and became known as the 'Berlin patient'. ${ }^{83}$ This was an HIV seropositive male who after receiving an allogeneic bone marrow graft carrying the homozygous CCR5- $\Delta 32$ alleles for treatment of acute leukemia remained free of HIV viral rebound for up to twenty months after his bone marrow transplant and discontinuation of ART, a status that has remained stable until now. The serendipitous success of this case opened the door for targeted gene therapy and the use of autologous transplantation of genetically modified CD4-positive T cells or even stem cells which, by the way, still require myeloablation as a major therapeutic challenge. ${ }^{84}$ Another potential approach in gene therapy involves the use of small RNAs, such as siRNAs, to interfere with posttranscriptional gene silencing and interference with HIV replication. ${ }^{85}$ The major challenge with RNA-based therapies lies with their potential in inducing an endogenous effect and in-vivo toxicity. ${ }^{84}$

\section{HIV receptor, coreceptor inhibition}

CCR5 antagonists are the new class of antiretroviral agents that are targeted to HIV entry into the host cell. They include maraviroc, available commercially, and vicriviroc and centriviroc that are in clinical testing. ${ }^{47,86-87}$ A viral assay (Trofile Assay; Monogram Biosciences San Francisco, CA, USA) has been developed to determine the proportion of the HIV viruses in an individual with the R5 strain. ${ }^{88}$ By using information obtained from this assay, the CCR5 antagonist maraviroc has entered clinical use for blocking HIV entry in individuals who are primarily infected with the R5 strain. Among other drugs targeting HIV entry, are several monoclonal antibody formulas against CCR5 and ibalizumab, the monoclonal antibody against the V3 loop of GP 120, that are still in development and testing. ${ }^{89-92}$

\section{Enhancing the innate host immune factors}

New approaches to ARV development include targeting innate immune responses shown to be effective in HIV suppression. Some of the targets include 'APOBEC 3G' that interferes with viral DNA synthesis, 'Tetherin' that blocks viral release and TRIM $\alpha$ that destabilizes the HIV capsid and interferes with reverse transcription. ${ }^{93-97}$ Another candidate target is 'LEDGF/p75', an integrase enzyme cofactor, whose antagonists are being studied for their ability to suppress HIV replication. ${ }^{98}$ Other possible ARV mechanisms involve the endogenously secreted antimicrobial peptides such as defensins, lactoferrins, secretory leukocyte protease inhibitor and Trappin-2/Elafin that all have shown to possess strong anti-HIV properties. ${ }^{95-96}$

Elimination of the HIV reservoirs and chronic immune activation Effective antiretroviral therapy leads to plasma HIV-RNA levels that are below the detection limit of the commonly used viral assays. However, for most individuals, a residual low-level viremia can be detected by ultrasensitive assays and the interruption of treatment results in a rapid viral rebound even after long-term ART use; these factors make HIV eradication from all the viral reservoirs a major challenge in its medical management. ${ }^{99}$ While plasma HIV-RNA is a virological marker for HIV disease progression, the HIV-DNA levels in peripheral blood monononuclear cells reflect the magnitude of the intracellular HIV reservoirs that also include the latently infected memory T cells. Although the exact dynamic of these viral reservoirs is not fully understood, the reactivation of the integrated HIV from the dormant cells is responsible for the viral rebound after discontinuation of ART, whereas ongoing viral replication in these cells may explain the sustained low level viremia among patients receiving ART. ${ }^{100}$ Treatment strategies aiming to activate the latent cells and making them more sensitive to host immune mechanisms have included the 
use of cytokines like IL-2 and IL-7, raltegravir and CCR5 antagonists, all in addition to the use of ART. ${ }^{101-103}$

Chronic immune activation with polyclonal B-cell activation, increased T-cell turnover and increased serum levels of pro-inflammatory cytokines and chemokines is a common feature of chronic HIV infection. ${ }^{104}$ The sustained immune activation not only leads to progressive loss of CD4 $\mathrm{T}$ cells and their depletion, but also promotes thrombosis and other aging-related diseases; this can be demonstrated by sustained levels of inflammatory markers such as IL- 6 and the coagulation marker, the d-dimer, in plasma. ${ }^{105-106}$ In fact, the gut-associated lymphoid tissue is a prime target early in the course of HIV infection and remains a chronically infected tissue and a main reservoir for the dormant $\mathrm{T}$ cells in the course of HIV infection and progression. ${ }^{107}$ Two treatment approaches have included the class of cox- 2 inhibitors and the lipid-lowering agent atorvastatin in conjunction with ART. ${ }^{108-109}$

\section{HIV vaccine}

The extraordinary diversity of HIV-1 throughout the world, its capacity to evade host immune responses, a lack of broadly reactive antibody response in most infections and the early establishment of latent viral reservoirs have been major obstacles for those in search of an effective HIV vaccine. ${ }^{110}$ Over the past two decades, two candidate vaccines have reached clinical efficacy studies, one used a monomeric HIV-1 Env gp120 protein aiming to induce Env-specific humoral immune responses $^{111-112}$ and the other used a recombinant adenovirus serotype vector expressing the main HIV-1 genes (Gag, Pol and Nef) to elicit HIV-1-specific cellular immune responses. ${ }^{113}$ Unfortunately, these approaches were shown ineffective in protecting against HIV infection as the rapid mutations in HIV envelope glycoproteins rendered the Envspecific antibodies ineffective and the cellular immune responses did not provide adequate immunity against infection. ${ }^{114-115}$ More recently, the identification of a broadly reactive neutralizing antibody activity in elite controllers $^{116}$ has redirected the HIV vaccine discovery efforts to the potential use of these natural antibodies as templates for developing a broadly neutralizing antibody-based vaccine in the near future. ${ }^{117}$

\section{SUMMARY}

Major scientific advances of the past 30 years have paved the way for therapeutic agents that can effectively suppress HIV viral replication. A major challenge in HIV eradication is the presence of HIV reservoirs that persist, despite effective treatments and optimal medication adherence and require lifelong treatment for those infected. Future treatments will focus on targeting these reservoirs and also on reducing the role of chronic inflammatory conditions and comorbidities that promote HIV disease progression. Efforts in developing an effective vaccine are promising and, if the current trends in developping new HIV treatment and prevention approaches continue, the global target of zero new infections may soon be realized.

\section{ACKNOWLEDGEMENTS}

Publication of this manuscript is supported by Open Fund of State Key Laboratory of Oral Diseases, Sichuan University.

1 Centers for Disease Control. Kaposi's sarcoma Pneumocystis pneumonia among homosexual men-New York City and California. Morbid Mortal Wkly Rep 1981 30(25): 305-308.

2 Vieira J, Frank F, Spira TJ et al. Acquired immunodeficiency in Haitians: opportunistic infections in previously healthy Haitian immigrants. N Engl J Med 1983; 308(3) 125-129.

3 Centers for Disease Control. Pneumocystis carinii pneumonia among persons with hemophilia A. Morbid Mortal Wkly Rep 1982; 31(27): 365-367.
4 Centers for Disease Control. Update on acquired immune deficiency syndrome (AIDS) among patients with hemophilia A. Morbid Mortal Wkly Rep 1982; 31(48): 644-646.

5 Centers for Disease Control. Update on acquired immune deficiency syndrome (AIDS) among patients with hemophilia A. Morbid Mortal Wkly Rep 1982; 31(48): 652

6 Centers for Disease Control. Possible transfusion-associated acquired immune deficiency syndrome (AIDS)—California. Morbid Mortal Wkly Rep 1982; 31(48): 652-654.

7 Centers for Disease Control. Update on acquired immune deficiency syndrome (AIDS)_United States. Morbid Mortal Wkly Rep 1982; 31(37): 507-508, 513-514.

8 Centers for Disease Control. Immunodeficiency among female sexual partners of males with acquired immune deficiency syndrome (AIDS)—New York. Morbid Mortal Wkly Rep 1983; 31(52): 697-698.

9 Harris C, Small CB, Klein RS et al. Immunodeficiency in female sexual partners of men with the acquired immunodeficiency syndrome. N Eng/ J Med 1983; 308(20): 11811184.

10 Barri-Sinoussi F, Chermann JC, Rey F et al. Isolation of a T-lymphotropic retrovirus from a patient at risk for acquired immune deficiency syndrome (AIDS). Science 1983; 220(4599): 868-871.

11 Popovic M, Sarngadharan MG, Read E et al. Detection, isolation, and continuous production of cytopathic retroviruses (HTLV-III) from patients with AIDS and preAIDS. Science 1984; 224(4648): 497-500.

12 Coffin J, Haase A, Levy JA et al. Human immunodeficiency viruses. Science 1986; 232(4751): 697.

13 Barre-Sinoussi F, Mathur-Wagh U, Rey F et al. Isolation of Iymphadenopathyassociated virus (LAV) and detection of LAV antibodies from US patients with AIDS. J Am Med Assoc 1985; 253(12): 1737-1739.

14 Clavel F, Guétard D, Brun-Vézinet $F$ et al. Isolation of a new human retrovirus from West African patients with AIDS. Science 1986; 233(4761): 343-346.

15 Keele BF, van Heuverswyn F, Li Y et al. Chimpanzee reservoirs of pandemic and nonpandemic HIV-1. Science 2006; 313(5786): 523-526.

16 Plantier JC, Leoz M, Dickerson JE et al. A new human immunodeficiency virus derived from gorillas. Nat Med 2009; 15(8): 871-872.

17 Santiago ML, Range F, Keele BF et al. Simian immunodeficiency virus infection in free-ranging sooty mangabeys (Cercocebus atys atys) from the Taï Forest, Côte d'Ivoire: implications for the origin of epidemic human immunodeficiency virus type 2. J Virol 2005; 79(19): 12515-12527. Erratum in: J Virol 2006; 80(9): 4645.

18 Piot P. Ingredients fro a perfect storm. Science 2011; 23(334): 1642.

19 Pépin J. The expansion of HIV-1 in colonial Leopoldville, 1950s: driven by STDs or STD control? Sex Transm Infect 2012; 88(4): 307-312.

20 UNAIDS. World AIDS day report 2011. Geneva: UNAIDS. Available at http:// www.unaids.org/en/media/unaids/contentassets/documents/unaidspublication/2011/ jc2216_worldaidsday_report_2011_en.pdf (accessed 5 December 2012).

21 UNAIDS. AIDS epidemic update. Joint United Nations Programme on HIV/AIDS (UNAIDS) and World Health Organization (WHO) 2009. UNAIDS/09.36E/ JC1700E, November 2009. Geneva: UNAIDS. Available at http://data.unaids.org/ pub/Report/2009/JC1700_Epi_Update_2009_en.pdf (accessed 5 December 2012).

22 Gonda MA. Molecular genetics and structure of the human immunodeficiency virus. Electron Microsc Tech 1988; 8(1): 17-40.

23 Montagnier L. Lymphadenopathy-associated virus: from molecular biology to pathogenicity. Ann Intern Med 1985; 103(5): 689-693.

24 Gelderblom HR, Hausmann EH, Ozel M et al. Fine structure of human immunodeficiency virus (HIV) and immunolocalization of structural proteins. Virology 1987; 156(1): 171-176.

25 Levy JA. Pathogenesis of human immunodeficiency virus infection. Microbiol Rev 1993; 57(1): 183-289.

26 Maddon P, Dalgleish A, McDougal JS et al. The T4 gene encodes the AIDS receptor and is expressed in the immune system and the brain. Cell 1986; 47(3): 333-348.

27 Gao G, Wieczorek L, Peachman KK et al. Designing a soluble near full-length HIV-1 GP41 trimer. J Biol Chem 2012; 288(1): 234-246.

28 Berger EA, Murphy PM, Farber JM et al. Chemokine receptors as HIV-1 coreceptors: roles in viral entry, tropism, and disease. Annu Rev Immunol 1999; 17: 657-700.

29 Sattentau QJ, Moore JP. Conformational changes induced in the human immunodeficiency virus envelope glycoprotein by soluble CD4 binding. J Exp Med $1991 ; 174(2): 407-415$.

30 Berkowitz RD, Alexander S, Bare C et al. CCR5- and CXCR4-utilizing strains of human immunodeficiency virus type 1 exhibit differential tropism and pathogenesis in vivo. $J$ Virol 1998; 72(12): 10108-10117.

31 Alkhatib G, Combadiere C, Broder CC et al. CC CKR5: a RANTES, MIP-1alpha, MIP1 beta receptor as a fusion cofactor for macrophage-tropic HIV-1. Science 1996; 272(5270): 1955-1958.

32 Hwang S, Boyle T, Lyerly $\mathrm{H}$ et al. Identification of the $\mathrm{V} 3$ loop as the primary determinant of cell tropism in HIV-1. Science 1991; 253(5015): 71-74.

33 Wyatt R, Sodroski J. The HIV-1 envelope glycoproteins: fuseons, antigens, and immunogens. Science 1998; 280(5371): 1884-1888.

34 Hunt PW, Brenchley J, Sinclair E et al. Relationship between T cell activation and $\mathrm{CD}^{+}{ }^{+} \mathrm{T}$ cell count in HIV seropositive individuals with undetectable plasma HIV RNA levels in the absence of therapy. J Infect Dis 2008; 197(1): 126-133.

35 Choudhary SK, Vrisekoop N, Jansen CA et al. Low immune activation despite high levels of pathogenic human immunodeficiency virus type 1 results in long-term asymptomatic disease. J Virol 2007; 81(16): 8838-8842.

36 Quillent C, Oberlin E, Braun J et al. HIV-1-resistance phenotype conferred by combination of two separate inherited mutations of CCR5 gene. Lancet 1998; 351(9095): 14-18. 
37 Schliekelman P, Garner C, Slatkin M. Natural selection and resistance to HIV. Nature 2001; 411(6837): 545-546.

38 Faure E, Royer-Carenzi M. Is the European spatial distribution of the HIV-1-resistant CCR5-Delta32 allele formed by a breakdown of the pathocenosis due to the historical Roman expansion? Infect Genet Evol 2008; 8(6): 864-874.

39 Thèze J, Chakrabarti LA, Vingert B et al. HIV controllers: a multifactorial phenotype of spontaneous viral suppression. Clin Immunol 2011; 141(1): 15-30.

40 International HIV Controllers Study, Pereyra F, Jia X, McLaren PJ et al. The major genetic determinants of HIV-1 control affect HLA class I peptide presentation. Science 2010; 330(6010): 1551-1557.

41 Zhang $\mathrm{H}$, Yang B, Pomerantz RJ et al. The cytidine deaminase induces hypermutation in newly synthesized HIV-1 RNA. Nature 2003; 424(6944): 94-98.

42 Jin $X$, Wu H, Smith $\mathrm{H}$. APOBEC3G levels predict rates of progression to AIDS. Retrovirology 2007; 4: 20-27

43 Neil SJ, Zang T, Bieniasz PD. Tetherin inhibits retrovirus release and is antagonized by HIV-1 Vpu. Nature 2008; 451(7177): 425-530.

44 Schrofelbauer B, Yu Q, Zeitlin SG et al. Human immunodeficiency virus type $1 \mathrm{Vpr}$ induces the degradation of the UNG and SMUG uracil-DNA glycosylases. J Viro/2005; 79(17): 10978-10987.

45 US Food and Drug Administration. Antiretroviral drugs used in the treatment of HIV infection. Silver Spring: US FDA. Available at http://www.fda.gov/ForConsumers/ byAudience/ForPatientAdvocates/HIVandAIDSActivities/ucm118915.htm (accessed 5 December 2012)

46 Hammer SM, Saag MS, Schechter M et al. Treatment for adult HIV infection: 2006 recommendations of the International AIDS Society-USA panel. JAMA 2006; 296(7): 827-843.

47 AIDS Info. Guidelines for the use of antiretroviral agents in HIV-1-infected adults and adolescents. Rockville: AIDS Info. Available at http://aidsinfo.nih.gov/guidelines (accessed 12 July 2012)

48 Hosseinipour MC, van Oosterhout JJ, Weigel R et al. The public health approach to identify antiretroviral therapy failure: high-level nucleoside reverse transcriptase inhibitor resistance among Malawians failing first-line antiretroviral therapy. AIDS 2009; 23(9): 1127-1134.

49 Laspia MF, Rice AP, Mathews MB. HIV-1 Tat protein increases transcriptional initiation and stabilizes elongation. Cell 1989; 59(2): 283-292.

50 Huigen MC, Kamp W, Nottet HS. Multiple effects of HIV-1 trans-activator protein on the pathogenesis of HIV-1 infection. Eur J Clin Invest 2004; 34(1): 57-66.

51 Fiorentino DF, Zlotnik A, Vieira $P$ et al. IL-10 acts on the antigen-processing cell to inhibit cytokine production by Th1 cells. J Immunology 1991; 146(10): 3444-3451.

52 Alfano M, Poli G. The cytokine network in HIV infection. Curr Mol Med 2002; 2(8): 677-689.

53 Division of Global HIV/AIDS, Center for Global Health. Integrated prevention services for HIV infection, viral hepatitis, sexually transmitted diseases, and tuberculosis for persons who use drugs illicitly: summary guidance from CDC and the U.S. Department of Health and Human Services. MMWR Recomm Rep 2012; 61(RR-5): 1-40.

54 Murata H, Hruz PW, Mueckler M. The mechanism of insulin resistance caused by HIV protease inhibitor therapy. J Biol Chem 2000; 275(27): 20251-20254.

55 Dubé MP, Parker RA, Mulligan K et al. Glucose metabolism, lipid, and body fat changes in antiretroviral-naive subjects randomized to nelfinavir or efavirenz plus dual nucleosides. AIDS 2005; 19(16): 1807-1818.

56 Grunfeld C, Rimland D, Gibert CL et al. Association of upper trunk and visceral adipose tissue volume with insulin resistance in control and HIV-infected subjects in the FRAM study. J Acquir Immun Def Syndr 2007; 46(3): 283-290.

57 Lohse N, Hansen AB, Pedersen G et al. Survival of persons with and without HIV infection in Denmark, 1995-2005. Ann Intern Med 2007; 146(2): 87-95.

58 Lundgren JD, Battegay M, Behrens G et al. European AIDS Clinical Society (EACS) guidelines on the prevention and management of metabolic diseases in HIV. HIV Med 2008; 9(2): 72-81.

59 Grinspoon SK, Grunfeld C, Kotler DP et al. State of the science conference. Initiative to decrease cardiovascular risk and increase quality of care for patients living with HIV/ AIDS; executive summary. Circulation 2008; 118(6): 198-210.

60 Ghani KR, Oliver RT, Chinegwundoh F. Human immunodeficiency virus-associated prostate cancer: clinicopathological findings and outcome in a multi-institutional study. BJU Int 2008; 101(12): 1519-1523.

61 Walker UA, Tyndall A, Daikeler T. Rheumatic conditions in human immunodeficiency virus infection. Rheumatology 2008; 47(7): 952-959.

62 Powles T, Robinson D, Stebbing J et al. Highly active antiretroviral therapy and the incidence of non-AIDS-defining cancers in people with HIV infection. $J$ Clin Oncol 2009; 27(6): 884-890.

63 DAD Study Group, Friis-M $\varnothing$ ller N, Reiss P et al. Class of antiretroviral drugs and the risk of myocardial infarction. N Engl J Med 2007; 356(17): 1723-1735.

64 Hammer SM, Eron JJ Jr, Reiss P et al. Antiretroviral treatment of adult HIV infection, 2008 recommendations of the international AIDS Society-USA panel. JAMA 2008; 300(5): 555-570.

65 French MA, Lenzo N, John M et al. Immune restoration disease after the treatment of immunodeficient HIV infected patients with highly active antiretroviral therapy. HIV Med 2000; 1(2): 107-115.

66 Ratnam I, Chiu C, Kandala NB et al. Incidence and risk factors for immune reconstitution inflammatory syndrome in an ethnically diverse HIV type 1-infected cohort. Clin Infect Dis 2006; 42(3): 418-427.

67 Lipman M, Breen R. Immune reconstitution inflammatory syndrome in HIV. Curr Opin Infect Dis 2006; 19(1): 20-25.
68 Leidner RS, Aboulafia DM. Recrudescent Kaposi's sarcoma after initiation of HAART: a manifestation of immune reconstitution syndrome. AIDS Patient Care STDS 2005; 19(10): 635-644.

69 Office of National AIDS Policy. National HIV/AIDS Strategy for the United States. Washington: Office of National AIDS Policy, 2010. Available at http://www.whitehouse. gov/administration/eop/onap/nhas (accessed 5 December 2012).

70 Mazzeo $\mathrm{Cl}$, Flanagan EH, Bobrow EA et al. How the global call for elimination of pediatric HIV can support HIV-positive women to achieve their pregnancy intentions. Reprod Health Matters 2012; 20(39 Suppl): 90-102.

71 World Health Organization. New guidance on prevention of mother-to-child transmission of HIV and infant feeding in the context of HIV, 2010. Geneva: World Health Organization. Available at http://www.who.int/hiv/pub/mtct/PMTCTfactsheet/en/ index.html (accessed 12 December 2012).

72 UNAIDS. Countdown to zero: global plan towards the elimination of new HIV infections among children by 2015 and keeping their mothers alive. Geneva: UNAIDS, 2011. Available at http://www.unaids.org/en/media/unaids/contentassets/documents/unaidspublication/2011/ 20110609 JC2137_Global-Plan-Elimination-HIV-Children_en.pdf (accessed 10 December 2012).

73 Branson BM, Handsfield HH, Lampe MA et al. Revised recommendations for HIV testing of adults, adolescents, and pregnant women in health-care settings. Morbid Mortal Wkly Rep 2006; 55(RR-14): 1-17.

74 Cohen MS, Chen YQ, McCauley $M$ et al. Prevention of HIV-1infection with early antiretroviral therapy. N Eng/ J Med 2011; 365(6): 493-505.

75 Government of Kenya. Kenya AIDS Indicator Survey 2007. Nairobi: Government of Kenya, 2009, Available at http://nascop.or.ke/library/3d/Official_KAIS_Report_20091.pdf (accessed 17 December 2012).

76 Centers for Disease Control and Prevention. Diagnoses of HIV infection and AIDS in the United States and Dependent Areas, 2010. HIV Surveillance Report, Volume 22. Atlanta: CDC. Available at http://www.cdc.gov/hiv/surveillance/resources/reports/ 2010report/index.htm (accessed 5 December 2012).

77 CDC. Antiretroviral postexposure prophylaxis after sexual, injection-drug use, or other nonoccupational exposure to HIV in the United States. Morbid Mortal Wkly Rep 2005; 54(RR-02): 1-20.

78 CDC. Interim guidance: preexposure prophylaxis for prevention of HIV infection in men who have sex with men and women. Morbid Mortal Wkly Rep 2011; 60(3): 65-68.

79 CDC. Interim Guidance for clinicians considering the use of preexposure prophylaxis for the prevention of HIV infection in heterosexually active adults. Morbid Mortal Wkly Rep 2012; 61(31): 586-589.

80 Botswana Harvard AIDS Institute. Botswana Harvard AIDS Institute Partnership: Mochudi Prevention Project. Gaborone: Botswana Harvard AIDS Institute, 2011. Available at http://www.hsph.harvard.edu/bhp/research/hiv prevention/mochudi_prevention.html (accessed 3 July 2012).

81 AIDS HIV Prevention Trial Network. HTPN 071, population effects of antiretroviral therapy to reduce HIV transmission (PopART): a cluster randomized trial of the impact of a combination prevention package on population-level HIV incidence in Zambia and South Africa . Available at http://www.hptn.org/research_studies/hptn071.asp (accessed 3 July 2013).

82 Walensky RP. Combination HIV prevention: the value and interpretation of mathematical models. Curr HIV/AIDS Rep 2013; [Epub ahead of print].

83 Hütter G, Nowak D, Mossner M et al. Long-term control of HIV by CCR5 Delta32 Delta32 stem-cell transplantation. N Engl J Med 2009; 360(7): 692-698.

84 Chung J, Rossi JJ, Jung U. Current progress and challenges in HIV gene therapy. Future Virol 2011; 6(11): 1319-1328.

85 Davidson BL, McCray PB Jr. Current prospects for RNA interference-based therapies. Nat Rev Genet 2011; 12(5): 329-340.

86 Caseiro MM, Nelson M, Diaz RS et al. Vicriviroc plus optimized background therapy for treatment-experienced subjects with CCR5 HIV-1 infection: final results of two randomized phase III trials. J Infect 2012; 65(4): 326-335.

87 Klibanov OM, Williams SH, Iler CA. Cenicriviroc, an orally active CCR5 antagonist for the potential treatment of HIV infection. Curr Opin Investig Drugs 2010; 11(8): 940 950.

88 Monogram Biosciences. Trofile ${ }^{T M}$ - Monogram's co-receptor tropism assay. San Francisco: Monogram Biosciences. Available at http://www.monogrambio.com/414.aspx. (accessed 21 December 2012).

89 Boesecke C, Pett SL. Clinical studies with chemokine receptor-5 (CCR5)-inhibitors Curr Opin HIV AIDS 2012; 7(5): 456-462.

90 Schanzer J, Jekle A, Nezu J et al. Development of tetravalent, bispecific CCR5 antibodies with antiviral activity against CCR5 monoclonal antibody-resistant HIV-1 strains. Antimicrob Agents Chemother 2011; 55(5): 2369-2378.

91 Zhang MY, Yuan T, Li J et al. Identification and characterization of a broadly crossreactive HIV-1 human monoclonal antibody that binds to both gp120 and gp41. PLoS ONE 2012; 7(9): e44241.

92 Pace CS, Fordyce MW, Franco D et al. Anti-CD4 monoclonal antibody ibalizumab exhibits breadth and potency against HIV-1, with natural resistance mediated by the loss of a V5 glycan in envelope. J Acquir Immune Defic Syndr 2012; 62(1): 1-9.

93 Monajemi M, Woodworth CF, Benkaroun J et al. Emerging complexities of APOBEC3G action on immunity and viral fitness during HIV infection and treatment. Retrovirology 2012; 9: 35

94 Ali A, Wang J, Nathans RS et al. Synthesis and structure-activity relationship studies of HIV-1 virion infectivity factor (Vif) inhibitors that block viral replication. Chem Med Chem 2012; 7(7): 1217-1229.

95 Shankar EM, Velu V, Vignesh $\mathrm{R}$ et al. Recent advances targeting innate immunitymediated therapies against HIV-1 infection. Microbiol Immunol 2012; 56(8): 497-505. 
96 Ellegård R, Shankar EM, Larsson M. Targeting HIV-1 innate immune responses therapeutically. Curr Opin HIV AIDS 2011; 6(5): 435-443.

97 Shi J, Zhou J, Shah VB et al. Small-molecule inhibition of human immunodeficiency virus type 1 infection by virus capsid destabilization. J Virol 2011; 85(1): 542-549.

$98 \mathrm{Hu} \mathrm{G}$, Li X, Zhang X et al. Discovery of inhibitors to block interactions of HIV-1 integrase with human LEDGF/p75 via structure-based virtual screening and bioassays. J Med Chem 2012; 55(22): 10108-10117.

99 Palmer S, Josefsson L, Coffin JM. HIV reservoirs and the possibility of a cure for HIV infection. J Intern Med 2011; 270(6): 550-560.

100 Joos B, Fischer M, Kuster $\mathrm{H}$ et al. HIV rebounds from latently infected cells, rather than from continuing low-level replication. Proc Natl Acad Sci U S A 2008; 105(43): 16725-16730.

101 Dhamija N, Rawat P, Mitra D. Epigenetic regulation of HIV-1 persistence and evolving strategies for virus eradication. Subcell Biochem 2013; 61: 479-505.

102 Llibre JM, Buzón MJ, Massanella M et al. Treatment intensification with raltegravir in subjects with sustained HIV-1 viraemia suppression: a randomized 48-week study. Antivir Ther 2012; 17(2): 355-364.

103 Gutiérrez C, Díaz L, Vallejo A et al. Intensification of antiretroviral therapy with a CCR5 antagonist in patients with chronic HIV-1 infection: effect on T cells latently infected. PLOS ONE 2011; 6(12): e27864.

104 Brenchley JM, Price DA, Schacker TW et al. Microbial translocation is a cause of systemic immune activation in chronic HIV infection. Nat Med 2006; 12(12): 1365-1371.

105 Appay V, Sauce D. Immune activation and inflammation in HIV-1 infection: causes and consequences. J Pathol 2008; 214(2): 231-241.

106 Deeks SG, Phillips AN. HIV infection, antiretroviral treatment, ageing, and non-AIDS related morbidity. Br Med J 2009; 338: a3172.

107 Brenchley JM, Price DA, Douek DC. HIV disease: fallout from a mucosal catastrophe? Nat Immunol 2006; 7(3): 235-239.

108 Kvale, D, Ormaasen V, Kran AB et al. Immune modulatory effects of cyclooxygenase type 2 inhibitors in HIV patients on combination antiretroviral treatment. AIDS 2006; 20(6): 813-820.

109 Ganesan A, Crum-Cianflone N, Higgins J et al. High dose atorvastatin decreases cellular markers of immune activation without affecting HIV-1 RNA levels: results of a double-blind randomized placebo controlled clinical trial. J Infect Dis 2011; 203(6): 756-764.

110 Dan H, Barouch DH. Challenges in the development of an HIV-1 vaccine. Nature 2008; 455(7213): 613-619.

111 Mascola JR, Snyder SW, Weislow OS et al. Immunization with envelope subunit vaccine products elicits neutralizing antibodies against laboratory-adapted but not primary isolates of human immunodeficiency virus type 1. The National Institute of Allergy and Infectious Diseases AIDS Vaccine Evaluation Group. J Infect Dis 1996; 173(2): 340-348.

112 Moore JP, Cao Y, Qing L et al. Primary isolates of human immunodeficiency virus type 1 are relatively resistant to neutralization by monoclonal antibodies to gp120, and their neutralization is not predicted by studies with monomeric gp120. J Virol 1995; 69(1): 101-109.

113 Priddy FH, Brown D, Kublin J et al. Safety and immunogenicity of a replicationincompetent adenovirus type $5 \mathrm{HIV}-1$ clade $\mathrm{B}$ gag/pol/nef vaccine in healthy adults. Clin Infect Dis 2008; 46(11): 1769-1781.

114 The rgp120 HIV Vaccine Study Group. Placebo-controlled phase 3 trial of a recombinant glycoprotein 120 vaccine to prevent HIV-1 infection. J Infect Dis 2005; 191(5): 654-665.

115 Fauci AS. The release of new data from the HVTN 502 (STEP) HIV vaccine study. NIH News 2007. Available at http://www.niaid.nih.gov/news/newsreleases/2007/ Pages/step_11707.aspx (accessed 17 December 2012).

$116 \mathrm{Li} \mathrm{Y}$, Migueles SA, Welcher B et al. Broad HIV-1 neutralization mediated by CD4binding site antibodies. Nat Med 2007; 13(9): 1032-1034.

117 van Gils MJ, Sander RW. Broadly neutralizing antibodies against HIV-1: templates for a vaccine. Virol 2013; 435(1): 46-56.

(c) This work is licensed under a Creative Commons Attribution-NonCommercial-NoDerivative Works 3.0 Unported License. To view a copy of this license, visit http:// creativecommons.org/licenses/by-nc-nd/3.0 